論文

\title{
高速実験炉「常陽」の原子炉容器内観察・補修技術開発 炉心上部機構の交換作業
}

\author{
高松 操 1 ,*, 川原 啓孝 ${ }^{1}$, 伊藤 裕道 ${ }^{1, \dagger 1}$, 宇敷 洋 ${ }^{1, \dagger 2}$, 鈴木 信弘 ${ }^{1, \dagger 3}$,

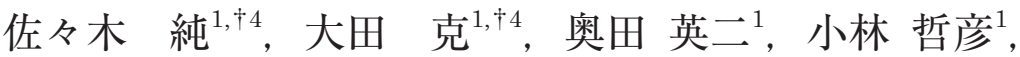 \\ 長井 秋則 ${ }^{1}$, 坂尾 龍太 ${ }^{2, \dagger 5}$, 村田 長太郎 ${ }^{2}$, 田中 淳也 ${ }^{2}$, \\ 松坂 康智 ${ }^{2}$, 立野 高寛 ${ }^{2}$, 原 正秀 $^{2}$, 岡㠃 弘祥 $^{2}$
}

\author{
Development of Inspection and Repair Techniques for \\ Reactor Vessel of Experimental Fast Reactor "Joyo" \\ Replacement of Upper Core Structure
}
Misao TAKAMATSU ${ }^{1, *}$, Hirotaka KAWAHARA ${ }^{1}$, Hiromichi ITO ${ }^{1, \uparrow 1}$, Hiroshi USHIKI ${ }^{1, \uparrow 2}$, Nobuhiro SUZUKI ${ }^{1, \uparrow 3}$, Jun SASAKI ${ }^{1, \uparrow 4}$, Katsu OHTA ${ }^{1, \dagger 4}$, Eiji OKUDA ${ }^{1}$, Tetsuhiko KOBAYASHI ${ }^{1}$, Akinori NAGAI ${ }^{1}$, Ryuta SAKAO ${ }^{2, \dagger 5}$, Chotaro MURATA ${ }^{2}$, Jyunya TANAKA ${ }^{2}$, Yasunori MATSUSAKA ${ }^{2}$, Takahiro TATSUNO ${ }^{2}$, Masahide HARA ${ }^{2}$ and Hiroyoshi OKAZAKI ${ }^{2}$
${ }^{1}$ Oarai Research and Development Center, Japan Atomic Energy Agency, 4002 Narita, Oarai-machi, Higashiibaraki-gun, Ibaraki 310-1393, Japan
${ }^{2}$ Nuclear Energy Systems Division, Energy \& Environment, Mitsubishi Heavy Industries, Ltd., 1-1 Wadasaki-cho 1-chome, Hyogo-ku, Kobe 652-8585, Japan

(Received April 28, 2015; accepted in revised form September 17, 2015; published online January 26, 2016)

In the experimental fast reactor "Joyo", it was confirmed that the top of the irradiation test subassembly of the material testing rig named "MARICO-2" was broken and bent onto the in-vessel storage rack as an obstacle, damaging the upper core structure (UCS). In this paper, we describe the in-vessel repair techniques for UCS replacement, which are developed in Joyo. The UCS replacement was conducted in the following four stages: (1) jack-up of the existing damaged UCS, (2) retrieval of the existing damaged UCS, (3) installation of the O-ring, and (4) insertion of the new UCS. Since the UCS replacement was not anticipated in the original design, the work conditions at Joyo were carefully investigated, and the obtained results were applied to the design of special handling equipment. The UCS replacement was successfully completed in 2014. In-vessel repair techniques for sodium-cooled fast reactors (SFRs) are important in confirming the safety and integrity of SFRs. However, the techniques demonstrated in the actual reactor environment with high temperature, high radiation dose, and remaining sodium are insufficient to secure the reliability of these techniques. The experience and knowledge accumulated in the UCS replacement provide valuable insights into further improvements of in-vessel repair techniques for SFRs.

KEYWORDS: FBR, sodium-cooled fast reactor, upper core structure, in-vessel inspection and repair, recovery, sodium, cover gas, MARICO-2, high temperature, high radiation dose

\footnotetext{
(国研) 日本原子力開発機構 大洗研究開発センター, ${ }^{2}$ 三菱重工業 $($ 株) エネルギー・環境ドメイン 原子力事業部

* Corresponding author, E-mail: takamatsu.misao@jaea.go.jp

${ }^{\dagger 1}$ 三菱重工業(株) (Mitsubishi Heavy Industries, LTD.)より出向， ${ }^{\dagger 2}$ 現在，三菱 FBR システムズ(株) (Mitsubishi FBR Systems, INC.)

${ }^{\dagger 3}$ 東興機械工業(株) (Tohkou Machine Industry, Co. LTD.) より出向, ${ }^{\dagger 4}$ (株)アセンド (Ascend, Co. LTD.)より出向

${ }^{\dagger 5}$ 現在, (国研) 日本原子力開発機構 (Japan Atomic Energy Agency)

(C) 2016 Atomic Energy Society of Japan, All Rights Reserved. 


\section{I. 緒言}

高速実験炉「常陽」は, 我が国で最初の高速増殖炉とし て，1977 年に増殖炉心 (MK-I 炉心) で初臨界を達成し， その後, 照射用炉心 (MK-II 炉心：1982 年に初臨界達成) を経て, 現在, 高性能照射用炉心 (MK-III 炉心 : 2003 年 に初臨界達成)での運転により, 高速増殖炉実用化に向け た燃料・材料開発等に供されてきた。しかしながら, 2007 年に「計測線付実験装置 (以下,「MARICO-2」) との 干渉による回転プラグ燃料交換機能の一部阻害」が発生 し, 現在, 停止状態にある。当該トラブルに関わる原子炉 容器内観察結果を Fig. 1 に示す。Fig. 1 に示すように, このトラブルにより, MARICO-2の一部(以下，「試料 部」)が原子炉容器内の燃料貯蔵ラック上で破損・変形し, また, MARICO-2 試料部との接触により，炉心上部機構 (以下,「UCS」)の下端が部分的に損傷したことが確認さ れた ${ }^{1)}$ 。「常陽」では, MARICO-2 試料部の回収および UCS の交換に必要な技術の開発およびその作業手順の整 備を進め, 2014 年 5 月〜 12 月に MARICO-2 試料部回収 作業およびUCS 交換作業を完遂した。本報告は，このう ち，UCS の交換に関わる技術開発・作業手順整備に関す る成果を，作業実績等を踏まえて総括するものである。

\section{II. プラントの概要}

「常陽」は，熱出力 $140 \mathrm{MWt}$ のナトリウム冷却型高速 炉(以下,「SFR」)である。原子炉容器, 回転プラグおよび UCS の概略構造を Fig. 2 に示す。原子炉容器は, 内径約 $3.6 \mathrm{~m}$ ・高さ約 $10 \mathrm{~m}$ の円筒容器構造を有し, 炉心燃料集 合体等や炉内構造物を内包する。また, 内包する炉心燃料 集合体等を冷却するため, 原子炬容器にはナトリウムが充 填されており，原子炉停止中，その温度は約 $200^{\circ} \mathrm{C}$ に保た れる。原子炉容器内のナトリウムは自由液面を有し, 当該 液面上には，ナトリウムが化学的に活性であることを踏ま え，カバーガスとして不活性ガス（アルゴンガス：約 140 $\sim 160^{\circ} \mathrm{C}$ ) が充填される。原子炉容器上部に設置された回 転プラグ(UCS を含む)は, カバーガスバウンダリの役割 を果たしており，原子炉容器内へのアクセスは，回転プラ グにあらかじめ設けられた貫通孔を用いて行われる。な お, ナトリウム液位は, 通常, 原子炉容器出口配管の上方 (GL-6100 mm) に保持されるが，メンテナンス時におい ては，炉心崩壊熱が十分に小さいことを確認した上で，原 子炉容器内のナトリウムをドレンし，ナトリウム液位を変 更することができる。UCS 交換作業に当たっては，同時 期に実施する MARICO-2 試料部回収作業において集合体 頂部付近へのアクセスが必要となることを踏まえ, ナトリ ウム液位を集合体頂部より $50 \mathrm{~mm}$ 低い位置 (GL-9540 $\mathrm{mm}$ : 床下メンテナンスモード)としている。

回転プラグの一部であるUCS は, Fig. 2 に示すように 直径が最大約 $1,345 \mathrm{~mm}$, 高さが約 $6,330 \mathrm{~mm}$ の円筒構造
物であり，その下部には，整流板および集合体出口冷却材 温度測定用熱電対を有する。Fig. 1 に示すように, 今回, 炉心上部機構に設置されている集合体出口冷却材温度測定 用熱電対が変形し, 集合体の出口冷却材温度を正しく測定 できないこと，また，整流板に変形が生じたことを踏ま え, 炉心上部機構を交換することとした。

\section{UCS 交換作業の概略手順}

UCS 交換作業の概略手順を Fig. 3 に示す。UCS 交換 作業は, 旧 UCS引抜作業および新 UCS 装荷作業に大別 される。各作業の概要を以下に示す。

\section{1. 旧 UCS 引抜作業の概要}

「常陽」の旧 UCS は，交換することを前提に設計され たものではなく，これまでに交換した実績も有していない ため, 旧UCS引抜作業にあっては, 以下の事象により, 当該作業の継続が困難となるリスクが懸念された。

・旧UCSが挿入されている案内スリーブは, 肉厚 $5 \mathrm{~mm}$ の薄肉構造物である。30 年以上の使用によ り, 旧 UCS と案内スリーブのギャップが, 蒸着ナ トリウムにより閉塞されている場合には, 旧 UCS 引抜時に当該ナトリウムをせん断することによる抵 抗(以下,「ナトリウムせん断抵抗」)が生じる。過大 なナトリウムせん断抵抗は, 案内スリーブに変形お よび損傷 (以下,「変形等」) を生じさせる恐れがあ る。

- 旧 UCS 太径部の外径が $\phi 1,060 \mathrm{~mm}$ (設計值)であ る一方で, 案内スリーブ細径部の内径は $\phi 1,070$ $\mathrm{mm}$ (設計值)であり, 旧 UCS 引抜時のギャップは 片側 $5 \mathrm{~mm}$ となる。旧 UCS 引抜時の水平度が十分 でない場合, 旧 UCS と案内スリーブが干渉もしく は接触(以下,「干渉等」)による抵抗 (以下,「干渉等 抵抗」)が生じる。過大な干渉等抵抗は, 旧 UCSに 変形等が生じさせる恐れがある。

上記事象の概念図を Fig. 4 に示す。これらの事象を防 止するためには, 引抜作業中の旧 UCS の水平度や水平方 向位置等を監視し, 旧 UCS を適切な状態に維持するこ と, さらに, ナトリウムせん断抵抗もしくは干渉等抵抗が 発生した場合にあっても, 旧 UCS 等を変形させないよう な荷重監視が必要となる。そのため, 旧 UCS引抜作業に おいては, 旧 UCS 太径部が案内スリーブ細径部を通過す るまでの範囲に相当する $1,000 \mathrm{~mm}$ 位置までの引抜作業 と $1,000 \mathrm{~mm}$ 位置以降の引抜作業を区分し，前者を「旧 UCS ジャッキアップ試験」，後者を「旧 UCS 収納作業」 とした。旧 UCS ジャッキアップ試験では，「IV. UCS 交 換作業に関わる技術開発および作業手順整備の概要」に示 す検討結果等を踏まえた上で, 旧 UCSを $1,000 \mathrm{~mm}$ 位置 まで引き抜くことで, 以下のデー夕を取得し，これまでの 検討の妥当性を検証することにより, 確実に引き抜くこと 


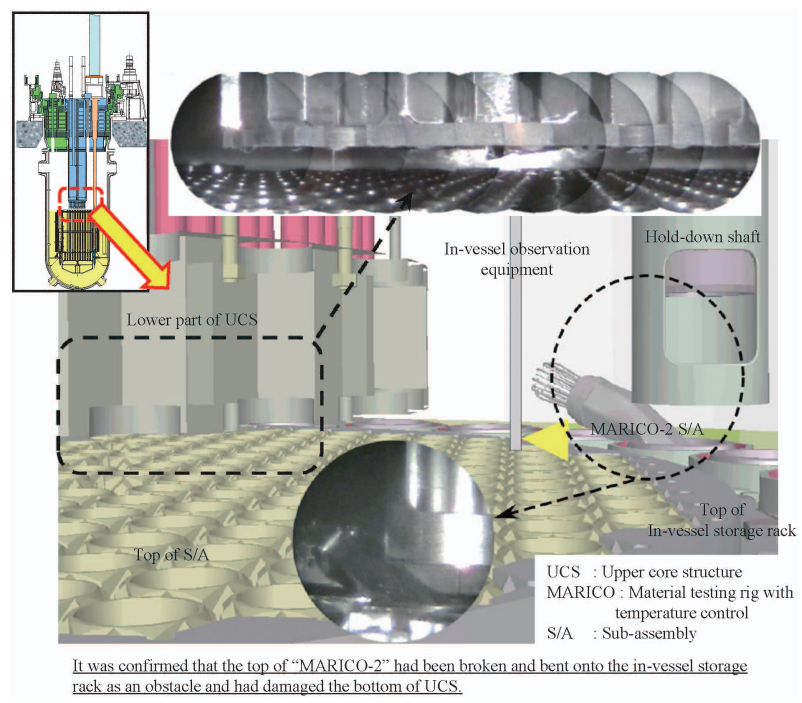

Fig. 1 Results of Joyo in-vessel observation

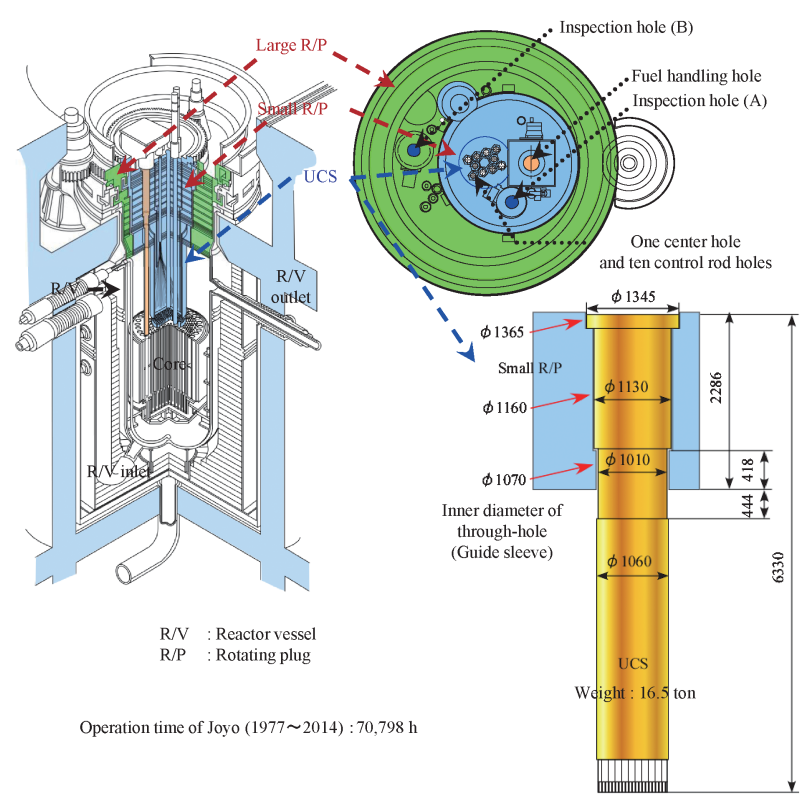

Fig. 2 Structure of reactor vessel, rotating plug and UCS

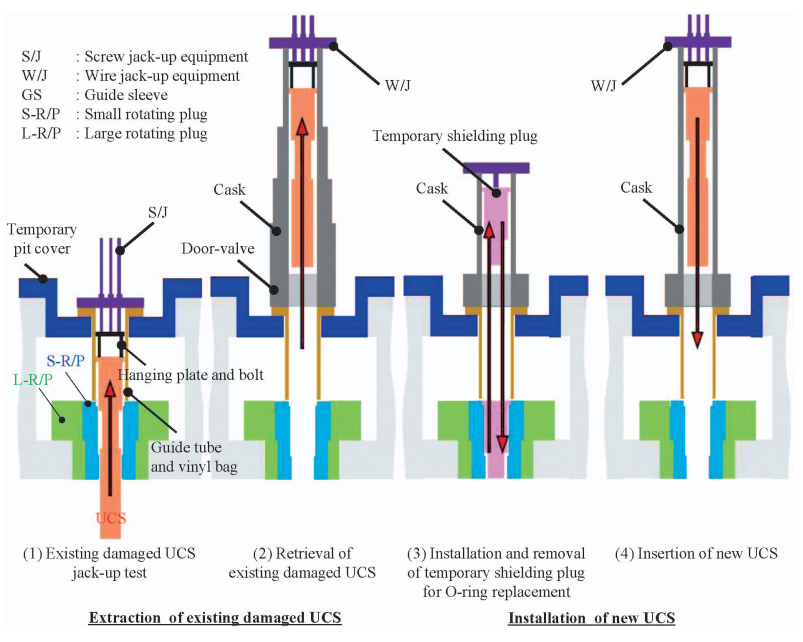

Fig. 3 Outline of UCS replacement

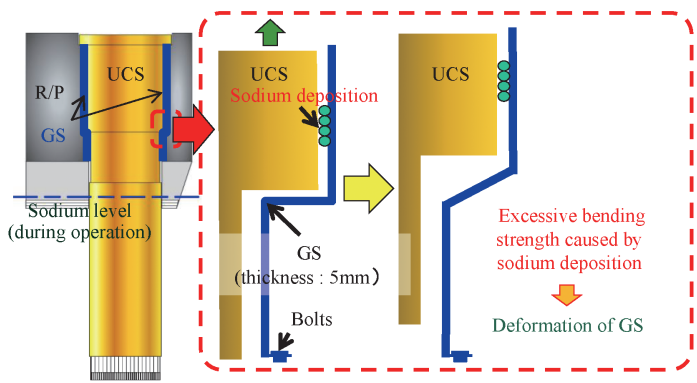

Deformation of GS due to sodium deposition

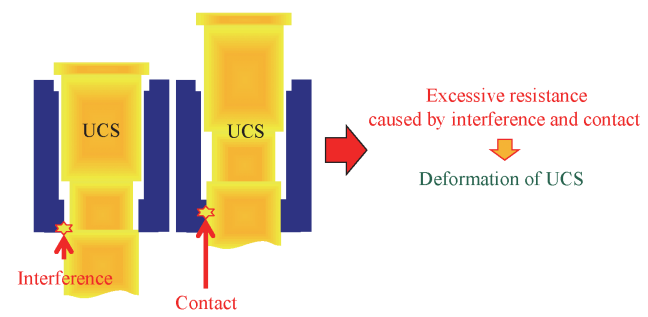

Deformation of UCS due to interference and contact between UCS and GS

Fig. 4 Risks in existing damaged UCS extraction

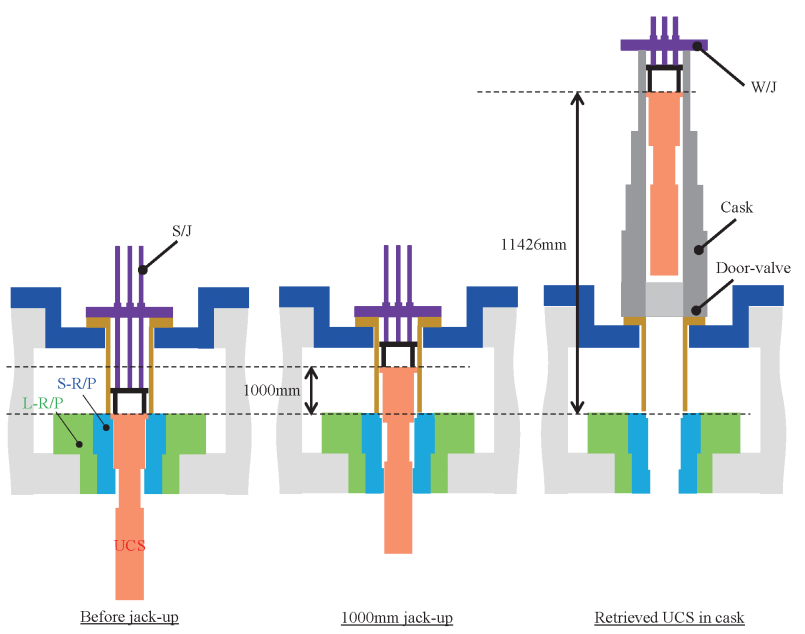

Fig. 5 Geometrical arrangement in existing damaged UCS extraction
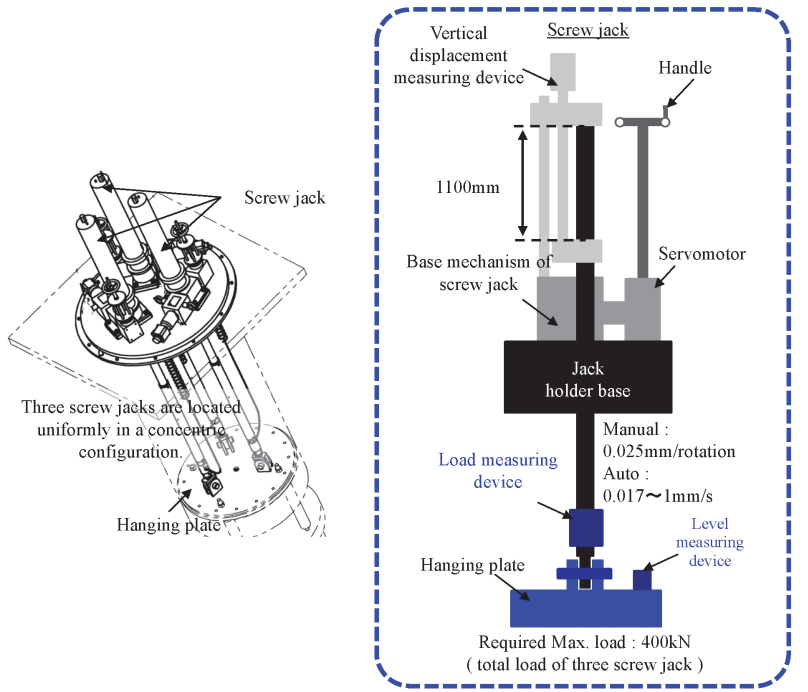

Fig. 6 Structure of screw jack-up equipment 
ができる見通しを得ることを目的としている。また，ホー ルドポイントとして旧 UCS 収納作業への移行可否を判断 することで, 当該作業が継続困難となるリスクの軽隇策と した。

・ナトリウムせん断抵抗に関わるデー夕取得(発生有 無確認/挙動確認/旧 UCS 引抜作業への影響確認 等)

・旧UCS引抜手順の妥当性を検証するためのデー夕 取得 (干涉等抵抗発生有無確認/挙動確認/旧 UCS 引抜作業への影響確認/旧 UCS 引抜位置最適化 デー夕取得等)

\section{2. 新 UCS 装荷作業の概要}

上述したように, UCS はカバーガスバウンダリの一部 を構成する。UCS 据付面は， 2 重 Oリング構造を有して

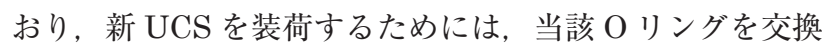
する必要がある。新UCS 装荷作業においては，作業環境 等に留意し, 新 UCS 用 $\mathrm{O}$ リングの設置作業を 1 つの久 テップと位置付け，新 UCS を挿入する前に実施すること

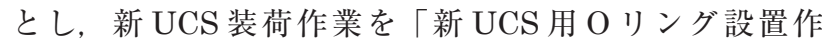
業」と「新UCS 挿入作業」に区分した。

\section{UCS 交換作業に関わる技術開発 および作業手順整備の概要}

1. 揚重設備に関わる技術開発および作業手順整備 （1）旧 UCS 引抜/新 UCS 挿入作業用揚重設備の概略 構造

旧 UCS ジャッキアップ試験では，上述したように，揚 重設備に高精度な水平度管理および荷重管理が要求され る。一方，旧 UCS 収納作業では，旧 UCS をキャスク内 に収納するため, 旧UCS を $11,426 \mathrm{~mm}$ 位置まで引き抜 くストロークを確保する必要がある。これらの要求事項に 対応するため, 旧 UCS ジャッキアップ試験(旧 UCS の 0 $\sim 1,000 \mathrm{~mm}$ 位置引抜) 用にジャッキアップ治具を, 旧 UCS 収納作業(旧 UCS の 1,000 11,426 mm 位置引抜) 用にワイヤジャッキ治具を開発し，実機に適用することと した ${ }^{2,3)}$ 。ジャッキアップ治具とワイヤジャッキ治具を用 いた旧UCS引抜イメージを Fig. 5 に示す。なお，新 UCS 挿入時にあっては, 新 UCS 太径部の外径を $\phi 1,050$ $\mathrm{mm}$ に低減して製作する等の挿入性向上策を講じており, 全ストロークについてワイヤジャッキ治具で対応すること とした。

\section{(a) ジャッキアップ治具の概略構造}

ジャッキアップ治具の概略構造を Fig. 6 に示す。ジャッ キアップ治具は, 3 本のネジジャッキを周方向均等に配置 した 3 点支持構造を有し, 吊蓋を介して旧 UCS に接続さ れる。旧UCSのジャッキアップに当たっては, 各ネジ ジャッキを同時に動作させることを基本とするが，独立に 単独動作させることも可能であり, 必要に応じて水平度を
調整できるようにしている。また, より精密な水平度調整 が求められる事象が発生した場合の対応として, ジャッキ アップ治具には手動操作機構を設けた。ネジジャッキの 1 つを単独で手動操作した場合, 旧UCS の水平度は, $0.0024^{\circ} /$ 回転 $(0.041 \mathrm{~mm} / \mathrm{m} /$ 回転 $)$ で微調整される。な お, 旧UCS の水平度は, 吊蓋上に設置された水準器によ り計測・監視される。各ネジジャッキはロードセルを有 し, 荷重の増減により干渉等を早期に検知し, 旧UCSや 案内スリーブの変形等を防止することができる。

（b）ワイヤジャッキ治具の概略構造

ワイヤジャッキ治具の概略構造を Fig. 7 に示す。ワイ ヤジャッキ治具は, ジャッキアップ治具と同様に, 3 本の ワイヤジャッキを周方向均等に配置した 3 点支持構造を 有する。また, 旧 UCS 引抜や新 UCS 挿入に当たっては, 各ワイヤジャッキを同時に動作させることを基本とする が, 独立して制御することも可能であり, 必要に応じて水 平度を調整できるようにしている。また，ワイヤジャッキ は，油圧ジャッキに連結された 2 つのクランプを有し， 1 動作当たりのストロークを最大 $300 \mathrm{~mm}$ とし, Fig. 7 に 示すように，順次これらのクランプを掴み替える(1 動作 当たりの最大ストローク： $300 \mathrm{~mm}$ )ことで, $11,426 \mathrm{~mm}$ 以上の引抜・挿入ストロークに対応できるものとしてい る。なお, 旧 UCSもしくは新 UCS の水平度は, 吊蓋上 に設置された水準器により計測・監視される。各ワイヤ ジャッキはロードセルを有し, 荷重の増減により干渉等を 早期に検知し, 旧 UCS もしくは新 UCS の変形等を防止 することができる。

（２）UCS と案内スリーブに干渉等が発生した場合の 揚重設備の運用手順整備

旧 UCS ジャッキアップ試験時および新 UCS 挿入作業 時には, UCS と案内スリーブが干渉もしくは接触し, 作 業継続が困難となるリスクが特に大きいため, 当該りスク の低減を目的とし，(1)干渉等が発生した位置を同定し，(2) 当該干渉等を回避する手順を整備するためのモックアップ 体を用いた干渉等模擬試験を実施した"

モックアップ体を用いた干渉等模擬試験の結果を Fig. 8 に示す。ここでは, 案内スリーブ模擬体に幅 $50 \mathrm{~mm}$ の 干渉板を設置し, UCS 模擬体と当該板が干渉した際の荷 重挙動デー夕を取得した。UCS が案内スリーブに干渉も しくは接触した場合には, その発生方向に重心が移動し, 3 本のジャッキに負荷される荷重のバランスに偏りが生じ る。この特性を利用し, 旧 UCS ジャッキアップ試験等で は, 取得された偏荷重デー夕に基づき重心の移動方向を逆 算し，干渉等が発生した位置を同定することとした。 Fig. 8 に示すように, 偏荷重デー夕に基づき算出した干渉 位置は，干渉板を設置した位置と抒打むね一致しており， 本手順が有効であることを確認した。

また，干渉等を回避する手順については，使用する揚重 設備が異なる(旧 UCS ジャッキアップ試験：ジャッキアッ 


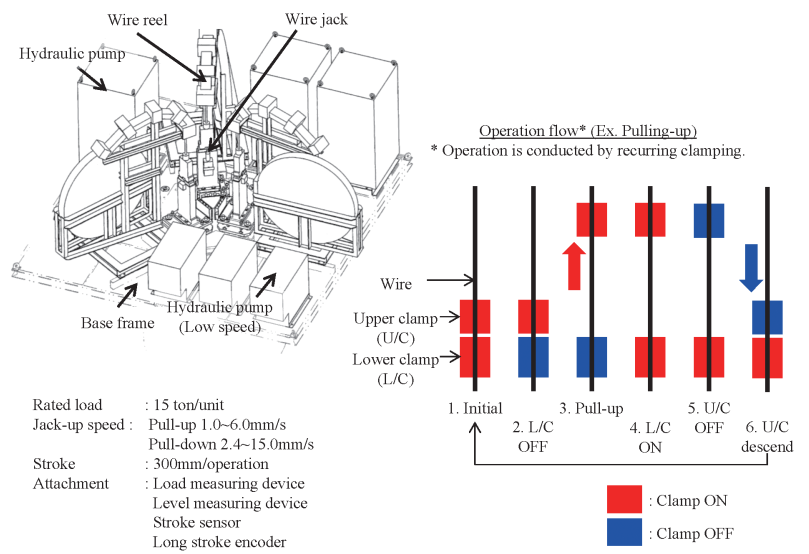

Fig. 7 Structure of wire jack-up equipment
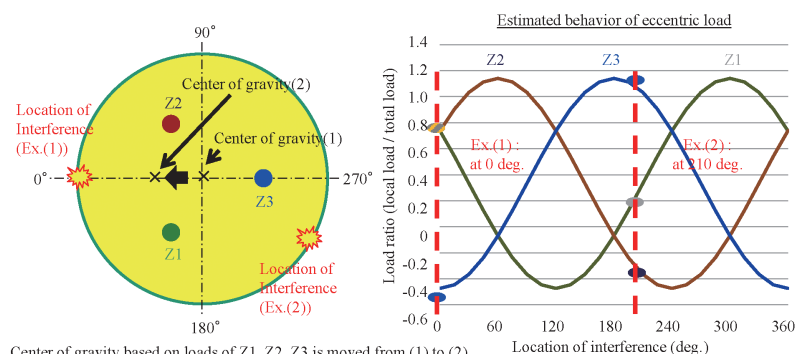

Center of gravity based on loads of Z1, Z2, Z3 is moved from (1) to (2)

》 $>$ Location of interference and contact is investigate
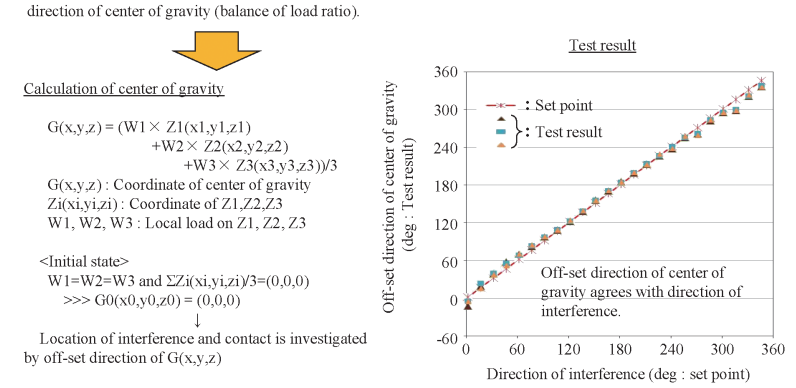

Fig. 8 Results of interference simulation test

プ治具/新 UCS 㨂入作業：ワイヤジャッキ治具) ため, 設 備に応じて対応方法を整備した。ジャッキアップ治具およ びワイヤジャッキ治具使用時の干渉等回避方策を Fig. 9 に示す。

ジャッキアップ治具については, 精密な水平度管理を実 現するため, 高い剛性を確保し, 旧UCS と一体構造化し ている。そのため, Fig. 9 に示すように, ジャッキアップ 治具はガイド筒上面に設置するものとし，ガイド筒に設け た水平方向位置調整用押しボルトにより, ガイド筒を水平 2 方向にスライドさせることで, 旧UCS の偏心を是正 し，旧UCS と案内スリーブの干渉等を回避できるように した。この対応方法については, 設計值で $5 \mathrm{~mm}$ である 旧 UCS と案内スリーブのギャップを，製作公差等を考慮 した上で保守的に最小 $0.65 \mathrm{~mm}$ としたモックアップ体を 用いた干渉等模擬試験により, 干渉検知・回避作業を繰り 返すことで, UCS 模擬体を $1,000 \mathrm{~mm}$ 位置までジャッキ アップできることを確認した。

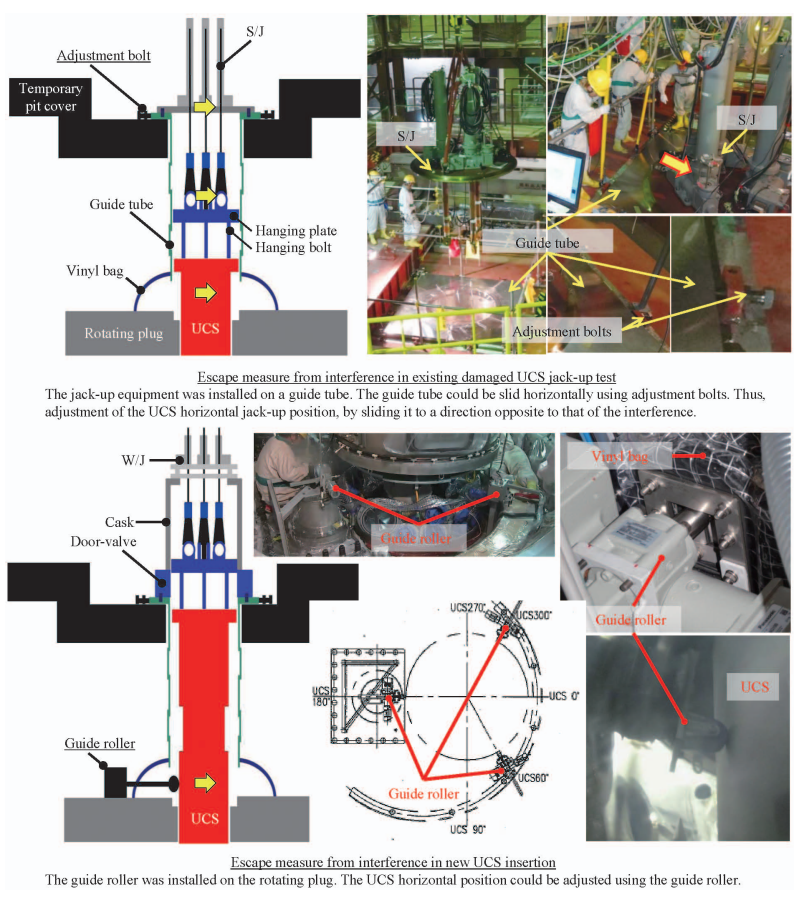

Fig. 9 Escape measure from interference between UCS and guide sleeve

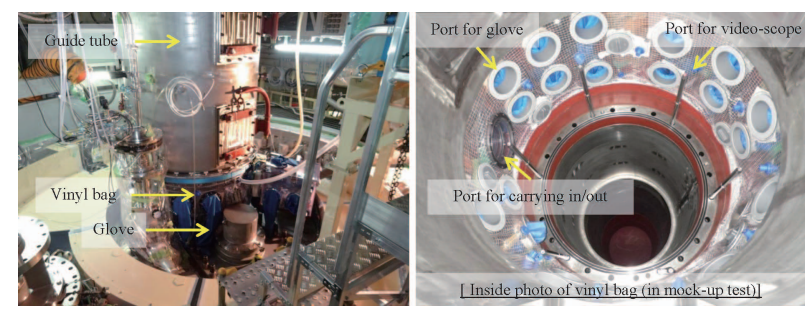

Fig. 10 Structure of vinyl bag

一方, ワイヤジャッキ治具については, 軟構造であるこ と，また，重量物であるドアバルブおよびキャスク（合計 約 130 t)の上部に設置される (Fig. 9 参照)ため，ガイド筒 をスライドさせることによる偏心是正手順が適用できない ことから，回転プラグ上面に設けたガイドローラーによ り, 新 UCS の偏心を是正し, 新 UCS と案内スリーブの 干渉等を回避できるようにした。

\section{2. カバーガスバウンダリ設備に関わる技術開発お よび作業手順整備}

\section{（1）カバーガスバウンダリ設備の概略構造}

UCS 交換作業時には, 鋼製のガイド筒, ドアバルブお よびキャスク等を設置した(Fig. 3 参照)上で, 小回転プラ グとガイド筒の間に, カバーガスバウンダリ設備としてビ ニルバッグを使用した。ビニルバッグの概略構造を Fig. 10 に示す。ビニルバッグは, グローブ用ポート, 治具類 搬出入用ポート，ビデオスコープ挿入用ポートを有し，ビ ニルバッグを介した作業や物品の出し入れおよびビニル バッグ内の観察が可能な構造となっている。ビニルバッグ 
の内部圧力は, ビニルバッグに設けたアルゴンガスの給排 気ラインにより制御される。また，ビニルバッグには，上 述のアルゴンガスの給排気ラインと別に, UCS 交換作業 中のビニルバッグ昇温を抑制するための冷却ラインが設置 されている。ビニルバッグ内のアルゴンガスの流れを Fig. 11 に示す。ビニルバッグ邻却用のアルゴンガスは, ガイド筒とビニルバッグ上部の接続部に設けられた冷却ラ インにより，ビニルバッグ内に供給される。なお，旧 UCS 収納作業時には, 旧 UCS とビニルバッグの接触を 防止するため, ビニルバッグ内側に防護板を設置してい る。当該防護板は, 治具類搬出入用ポートから出し入れ し，ビニルバッグ使用中に設置もしくは撤去できる構造を 有し，冷却用アルゴンガスの流路形成および輻射熱による ビニルバッグ昇温抑制の役割も果たしている。

\section{（２）カバーガスバウンダリの管理手順}

UCS 交換作業では, 原子炉容器内カバーガス圧力を別 途開発した循環型カバーガス微正圧制御システムにより 110 140 Paに制御する ${ }^{5)}$ 一方で, ビニルバッグ圧力を, 原子炉容器内カバーガス圧力より若干高めの 120〜150 $\mathrm{Pa}$ で制御することを基本とした。「常陽」において，カ バーガスバウンダリを開放する際には，空気等の不純物の 混入を防止するとともに，万一仮設のバウンダリに破損が 生じた場合のカバーガス放散を抑制するため，カバーガス 圧力を微正圧で保持しており, UCS 交換作業におけるカ バーガス圧力管理方法は，この方針を踏襲したものであ る。

原子炉容器内カバーガス圧力とビニルバック圧力は, 独 立に制御されるが, 旧UCS ジャッキアップ開始以降に あっては, 原子炉容器とビニルバックが導通するため, 高 温のカバーガスが上昇し，ビニルバッグの健全性が阻害さ れることがないよう，ビニルバッグ上方から，アルゴンガ スをブローダウンしている。Fig. 11 に示したように，ア ルゴンガスは，ビニルバッグから原子炉容器に流入する が, ビニルバッグ圧力は, 原子炉容器内カバーガス圧力に 追従して変動するため, 原子炉容器とビニルバックが導通

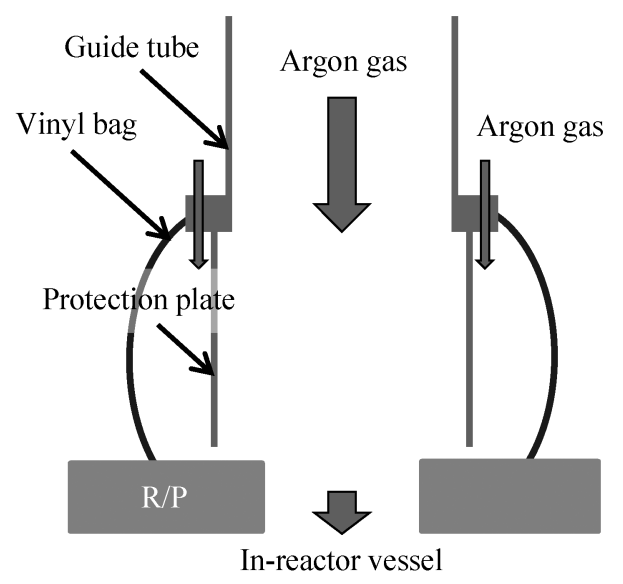

Fig. 11 Argon gas flow in vinyl bag
した状態での圧力制御は, 主に原子炉容器内カバーガス圧 力を制御する循環型カバーガス微正圧制御システムにより 実施される。アルゴンガスブローダウンは，上述したよう に, 高温のカバーガスの上昇抑制を目的としており, 必要 なアルゴンガスブローダウン流量は, 案内スリーブ内に構 造物 (旧 UCS 等) が存在し, ブローダウン面積 (ビニルバッ グから原子炉容器に流入するアルゴンガスの流路面積) が 小さい場合と案内スリーブ内に構造物がなく, ブローダウ ン面積が大きい場合とで異なることから，ここでは，アル ゴンガスブローダウン流量を旧 UCS ジャッキアップ試験 時には約 $5 \mathrm{~m}^{3} / \mathrm{h}$ 以上 (最大), 旧 UCS 収納作業時には約 $20 \mathrm{~m}^{3} / \mathrm{h}$ (最大)にする等, ブローダウン面積に応じて調整 した。なお，ここでは，約 $20 \mathrm{~m} / \mathrm{s}$ 以上の流速を確保した 上で, 作業員の近接の有無等の状況に応じた安全余裕も, 必要に応じて見込んでいる。

\section{V. フルモックアップ試験}

UCS 交換作業では，作業手順や機材運用方法を確認す るとともに，得られた知見等を作業要領書等に反映するた め, 事前に, 実機に使用する機材と実機大のモックアップ 体を用いたフルモックアップ試験を実施した。フルモック アップ試験では, 約 $13 \mathrm{~m} \times 13 \mathrm{~m} \times 10 \mathrm{~m}$ の試験架台に, 実機大のモックアップ体として, 小回転プラグ模擬体, 案 内スリーブ模擬体拉よびUCS 試験体等を設置することで 実機の作業環境を模擬した。なお，実機の案内スリーブの 下部は設計上, 内径 $\phi 1,070 \mathrm{~mm}$ の円形状を有するが, 案 内スリーブ模擬体の下部については，その製作公差や据付 時に歪み等が生じた可能性を考慮し, 長径 $\phi 1,070 \mathrm{~mm}$, 短径 $\phi 1,065 \mathrm{~mm}$ の棈円形状として, UCS 試験体と案内 スリーブ模擬体のギャップの一部が小さくなるようにし た。また, UCS 試験体は, 上部試験体と下部試験体で構 成し, ダミーウェイトを用いて実機の重量拈よび重心を模 擬するように調整した。フルモックアップ試験のうち，揚 重設備に関連して実施した「ジャッキアップ機能確認試 験」㧍よび「引抜/挿入性確認試験」等の概要および結果 を以下に示す。

\section{1. ジャッキアップ機能確認試験}

ジャッキアップ治具について一連の操作を実施し, 当該 治具の運用に関わるパラメータ(ストロークおよび引抜速 度他)の設定に関わるデー夕を取得するとともに，荷重お よび水平度を許容值内に制限しつつ, $0 \sim 1,000 \mathrm{~mm}$ 位置 までのジャッキアップ作業を確実に実施できる見通しを得 た。また，旧 UCS ジャッキアップ試験後に実施する Oリ ング回収作業に資するため, 実機と同様に, ビニルバッグ を介してリリングを回収するトレーニング等を実施した。

\section{2. 引抜/挿入性確認試験}

引抜/挿入性確認試験時における機器の挙動や配置等の 


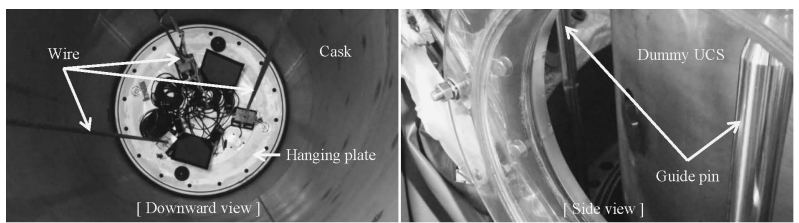

Confirmation of UCS Inclination during pulling-up

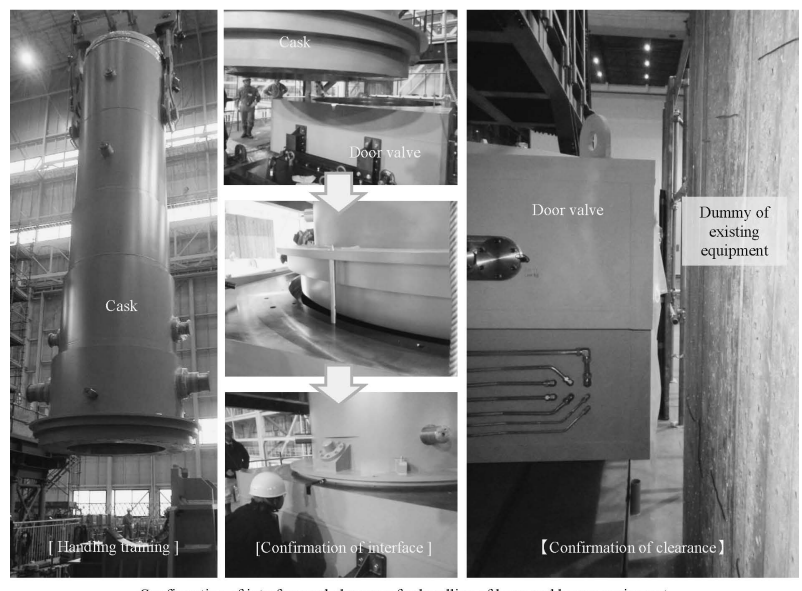

Fig. 12 Typical scene in full mock-up test

確認状況を Fig. 12 に示す。ここでは, UCS 試験体を上 部から視認し, 引抜および挿入時に生じる UCS 試験体の 振れ等を確認しつつ, ワイヤジャッキ治具に関わる一連の 操作を実施し, 当該治具の運用に必要なパラメータ(スト ローク，引抜速度および油圧）の設定に関わるデー夕を取 得するとともに，荷重および水平度を許容值内に制限しつ つ, 収納作業 $(1,000 \sim 11,426 \mathrm{~mm})$ および挿入作業 $(11,426$ 〜0 mm）を確実に実施できる見通しを得た。また，フル モックアップ試験の準備作業では，ドアバルブやキャスク 等の大型重量物をUCS 直上の所定の位置に設置するため の手順を検証するとともに，これらの設置に伴う仮設ピッ 卜蓋の撓み等の計測により, 実機作業においてキャスク等 の真直度を確保し，不要な偏心等を防止するために必要な データを取得した。

\section{3. 作業要領の策定に資するデータの取得等}

フルモックアップ試験では，ボルトの取り外しや取り付 けまでを網羅した一連の作業を実施することで，機材の設 置位置取合い, 設置手順, ハンドリング方法等を明確化 し，作業要領の策定に資するデー夕を取得するとともに， 作業員の習熟度向上を図った。

\section{UCS 交換作業}

旧 UCS ジャッキアップ試験を 2014 年 5 月 7 日に実施 し，5月22日に旧 UCSを引抜・収納した。また MARICO-2 試料部を回収した後, 11 月 20〜21日に新 UCS を装荷し，12月 17 日に後片付けを含めたすべての 作業を完了した。主な作業条件および作業結果を以下に示 す。

\section{1. プラント状態}

UCS 交換作業時のプラント状態を以下に示す。なお, 旧 UCS を引き抜くことで，通常のカバーガスバウンダリ が開放され，ビニルバッグ等の仮設機器によりカバーガス バウンダリを構成していることから, 原子炉容器からカ バーガスが流出するリスクを低減することを目的に，カ バーガス圧力は，通常より低いものとしている。
(1) ナトリウムレベル
(2)
カバーガス圧力 : 110 $140 \mathrm{~Pa}^{* 1}$
$170 \mathrm{~Pa}$ (最終調整值))した。
（3）ナトリウム温度 : 約 $200^{\circ} \mathrm{C}$
(4) カバーガス温度 : 約 $150^{\circ} \mathrm{C}$
（5）アルゴンガス供給系：運転
（6）廃ガス処理系 : 運転
（7） 1 次補助冷却系 : 停止

: GL-9540 mm

*1 : 循環型カバーガス微正圧制御システムに よりカバーガス圧力を制御(既設圧力制御 設備をバックアップとして使用：40〜

\section{2. 旧 UCS ジャッキアップ・収納／新 UCS 挿入 作業}

旧 UCS ジャッキアップ試験を 2014 年 5 月 7 日 $10: 30$ 〜 16: 20 に実施 ${ }^{6)} し$, 旧 UCSを $1,000 \mathrm{~mm}$ 位置とした 後, 5 月 22 日 $11: 00$ より旧 UCS 収納作業を開始し, $13: 58$ に11,426 mm 位置(上限位置) として旧 UCSを キャスクに収納した。また，新 UCS 挿入作業を 11 月 20 日 $10 ： 35$ より開始し, 翌 21 日 $2: 15$ に新 UCS の着座 (0 mm 位置)を完了した。旧 UCS ジャッキアップ・収納/ 新 UCS 挿入作業に関わる主な結果を以下に示す。

\section{（1）旧 UCS ジャッキアップ試験}

旧 UCS ジャッキアップ試験では，ナトリウムせん断抵 抗の有無および挙動を確認するため, まずは, 手動操作に て，旧 UCSを0〜2 mm 位置までジャッキアップした， その際の荷重測定結果を Fig. 13 に示す。旧UCS は原子 炉カバーガスのバウンダリを構成する機器であり, 旧 UCS のジャッキアップは, 計画外に旧 UCS が揚重され, 当該バウンダリが開放されることがないように，旧 UCS 設計重量である 16.5 トンを下回る約 15 トンの引抜荷重 を負荷した状態より開始した。なお，ジャッキアップ速度 は約 $2 \mathrm{~mm} / \mathrm{h}$ とした。約 $0.75 \mathrm{~mm}$ 位置までは引抜荷重が 上昇したものの, 当該位置以降は約 16.8 トンで推移して おり, ナトリウムせん断抵抗の発生は確認されなかった。 ただし，旧 UCS 側面にはナトリウムの付着が確認され た。旧UCS 側面のナトリウム付着状況を Fig. 14 に示 す。当該ナトリウムを回収し分析した結果から,これらは 約 $97.4 \mathrm{wt} \%$ の金属ナトリウムで構成されること，また， 目視および触感から, 密な金属結晶構造ではなく, 微粒子 が凝集・堆積した構造 (多孔性構造)を有すると推定される ことを確認した。ギャップ等に付着するナトリウムの性状 
や位置は，当該位置に至るまでの流路や温度分布，また， 純度管理の状況に依存するため, これを正確に予測するこ とは困難であるが，今回は，ナトリウムがせん断された形 跡もない(案内スリーブ表面にナトリウムが残存していな い)ことから，当該ナトリウムがせん断されるのではな く, 案内スリーブとの接触していた付着ナトリウムの表面 が脆性破壊し，案内スリーブ表面を滑る形となり，ナトリ ウムせん断抵抗が発生しなかったと考えられる。なお，当 該分析では，付着ナトリウムに含まれる Na-22 の濃度が $5.6 \mathrm{~Bq} / \mathrm{g}$ であることを確認した。 $\mathrm{Na}-22$ は, 安定同位体 である $\mathrm{Na}-23$ の $(\mathrm{n}, 2 \mathrm{n})$ 反応により生成される。半減期 (約 2.6 年)を考慮し, 逆減衰曲線により過去の分析結果と 比較した結果, MK-II 炉心運転初期の 1 次冷却材中の $\mathrm{Na}-22$ 濃度とおおむね一致する。この結果より, 当該付 着ナトリウムが, 1986 年以前 (約 28 年以上前)に堆積し たものであること, また, これ以降においては, ナトリウ ムの堆積が継続されなかったことを確認した。ナトリウム の堆積が継続されなかった原因としては, ナトリウムミス トの上昇ルートが閉塞したこと等が考えられる。

2 1,000 mm 位置ジャッキアップ時の荷重測定結果を Fig. 15 に示す。なお, これは, 干渉等により発生した荷 重を精度よく検知するため, 荷重計をゼロリセット (旧 UCS 等の自重をキャンセルアウト) したデータとなってい る。また, 適宜, 荷重均等化措置 (ネジジャッキの単独動 作による水平度調整) を実施し，ネジジャッキの同時動作 のズレにより生じる偏荷重を是正した。Fig. 15 に示すよ うに, 約 $750 \mathrm{~mm}$ 位置において, 旧 UCS と案内スリーブ に干渉等が生じたが, ジャッキアップ治具における高精度 な水平度管理および荷重管理が有効に機能し, 旧 UCS と 案内スリーブの干渉等をこの 1 回に限定することができ た。また，当該干渉等の発生時には，事前に整備した運用 手順に基づき, 水平方向位置調整用押しボルトにより, 引 抜位置を干渉等を回避する方向に約 $0.7 \mathrm{~mm}$ スライド (Fig. 9 参照)させることで干渉等を回避できており, 当該 手順が妥当であったことが確認できた。旧 UCS ジャッキ アップ試験では, 最終的に, 旧 UCSを $1,000 \mathrm{~mm}$ 位置ま でジャッキアップし, 次のステップである旧 UCS 収納作 業を問題なく実施できる見通しを得た。なお, 旧 UCS ジャッキアップ試験は, Fig. 15 に示したように, 最終的 に, 旧 UCS と案内スリーブの接触に起因する抵抗(もし くは, 蒸着ナトリウムに起因する抵抗)により, 総荷重が 約 1 トン増加した状態で終了している。

\section{（２）旧 UCS 収納作業および新 UCS 挿入作業}

旧 UCS 収納作業および新 UCS 挿入作業における荷重 測定結果を Fig. 16 に示す。旧 UCS 収納作業における初 期の総荷重は約 18.1 トンであったが, 引抜作業継続中 に, 旧 UCS と案内スリーブの接触に起因する抵抗(もし くは, 蒸着ナトリウムに起因する抵抗)が減少し, 約 4,250 mm 位置から上限位置である $11,426 \mathrm{~mm}$ 位置まで,
総荷重は約 17.3 トンでおおむね安定して推移し, 引抜操 作を問題なく完了させることができた。なお, 約 $4,250 \mathrm{~mm}$ 位置以降の引抜操作において, 総荷重に若干の変動が生じ ている。約 4,250 $\mathrm{mm}$ 位置以降の引抜操作において, 引 抜速度を変更したことに伴って, ワイヤを掴み替えた際に 生じる荷重バランス (水平度) の変化が大きくなったこと が, 当該変動の原因と推定される。

一方，新 UCS 挿入作業にあっては，Fig. 16 に示すよ うに, 総荷重は約 16.6 トンでおおむね安定に推移した。 約 4,472 mm 位置において, 新 UCS と案内スリーブに干 渉等が生じたものの, ワイヤジャッキ治具における高精度 な水平度管理および荷重管理が, ガイドローラーと相まっ て有効に機能し, 新 UCS 挿入作業の継続を阻害するよう な干渉等の発生をこの 1 回に限定することができた。ま た, 当該干渉等の発生時には, 事前に整備した運用手順に 基づき，ガイドローラーにより，挿入位置を約 $5 \mathrm{~mm}$ ス ライド(Fig. 9 参照)させることで, 干渉等を回避できてお り, 当該手順が妥当であったことが確認できた。新 UCS の着座時に使用する拘束治具の概要を Fig. 17 に示す。新 UCSの着座・据付に当たっては, 新 UCS を計画した位 置に対してェ $1.02 \mathrm{~mm}$ の精度で据え付けることが要求さ れており, 新UCS の着座に当たっては, 新 UCS フラン ジボルト孔にガイドボルトの先端が扦入されたことを確認 した後, Fig. 17 に示すように, 当該ボルト孔とガイドボ ルトとのギャップに拘束治具を設置することとした。当該 拘束治具は, 上述した要求精度を満足させるため, 新 UCS の据付精度を土約 $0.77 \mathrm{~mm}$ (実測值)に制限できるも のとしている。新 UCS 着座 - 据付後, 新 UCS 据付精度 を確認した結果, 新 UCS が, 計画した位置に対して, 最 大 $0.35 \mathrm{~mm} \pm 0.1 \mathrm{~mm}$ の誤差で据え付けられたことを確認 できた。

\section{3. カバーガスバウンダリ管理}

UCS 交換作業では, 事前に定めた管理手順に基づき, 原子炉容器内カバーガス圧力を $110 〜 140 \mathrm{~Pa}$ に制御する 一方で, ビニルバッグ圧力を $120 \sim 150 \mathrm{~Pa}$ で制御した。 また, 原子炉容器とビニルバックが導通した状態にあって は, アルゴンガスブローにより, 高温のカバーガスの上昇 を抑制し，ビニルバッグ温度をおおむね $60^{\circ} \mathrm{C}$ 以下で管理 することで, 作業期間中のカバーガスバウンダリの健全性 を確保した。なお, ビニルバッグ内側に設置した防護板に ついては, 特に, 旧 UCS 収納作業時において, 輻射熱に よるビニルバッグ昇温抑制の観点で有効であった。一方, 冷却用アルゴンガスの流路形成の観点では, 十分なアルゴ ンガスブローにより, 高温のカバーガスの上昇を抑制でき ることが旧 UCS 収納作業等において確認できたことか ら, 輻射熱に関わる対応を必要としない新 UCS 挿入作業 においては防護板を不要としている。 

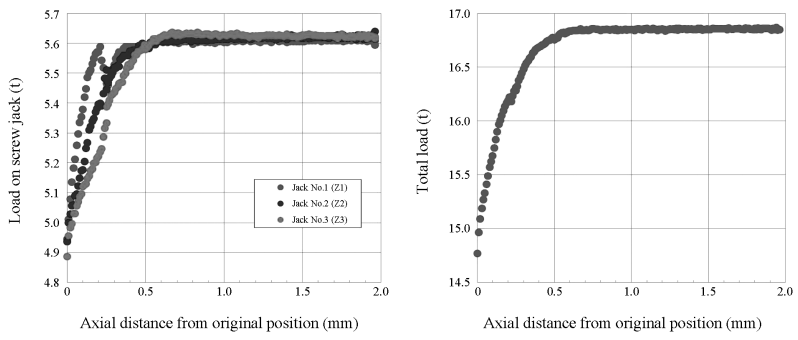

Fig. 13 Load behavior in existing damaged UCS jack-up from $0 \mathrm{~mm}$ to $2 \mathrm{~mm}$
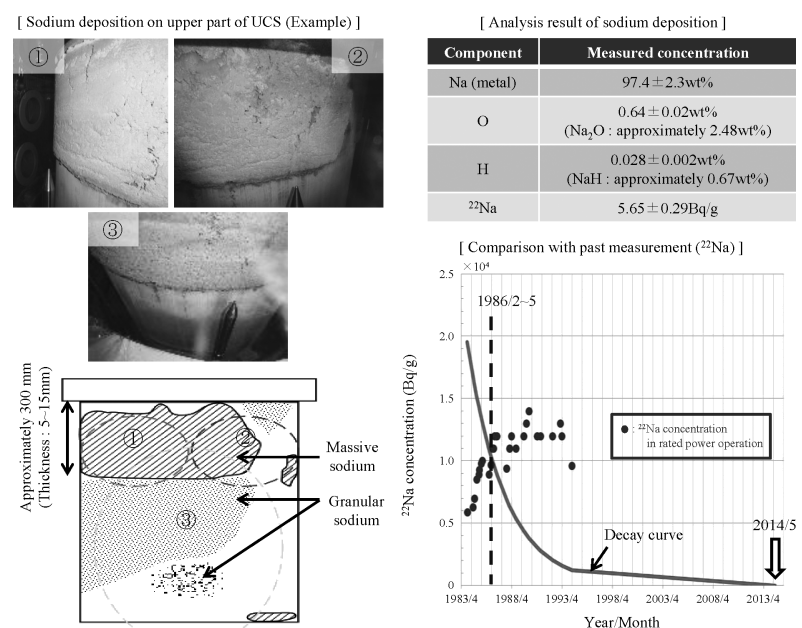

Fig. 14 Analysis result of sodium deposition on existing damaged UCS

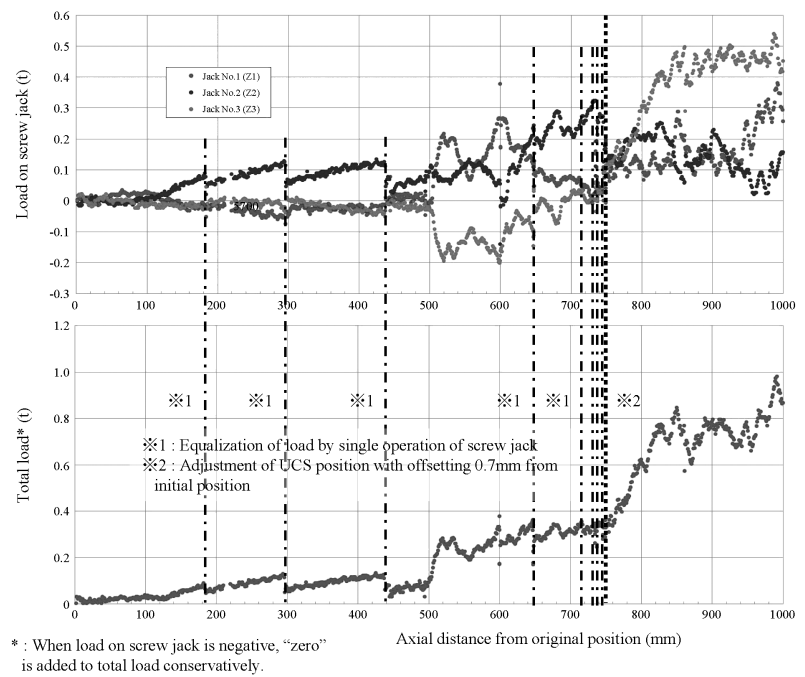

Fig. 15 Load behavior in existing damaged UCS jack-up from $2 \mathrm{~mm}$ to $1,000 \mathrm{~mm}$

\section{4. 放射線管理}

UCS 交換作業時の作業環境線量率測定結果の一例とし て，旧 UCS 収納作業時のエリアモニ夕指示值を Fig. 18 に示す。旧UCS は，長年に渡る使用により放射化し，高 い表面線量率を有するため, 仮設ピット蓋, ドアバルブや

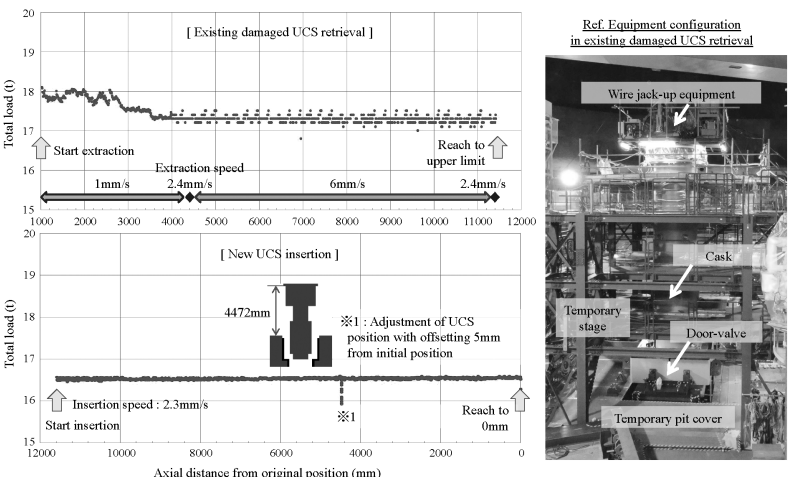

Fig. 16 Load behaviour during existing damaged UCS retrieval and new UCS insertion

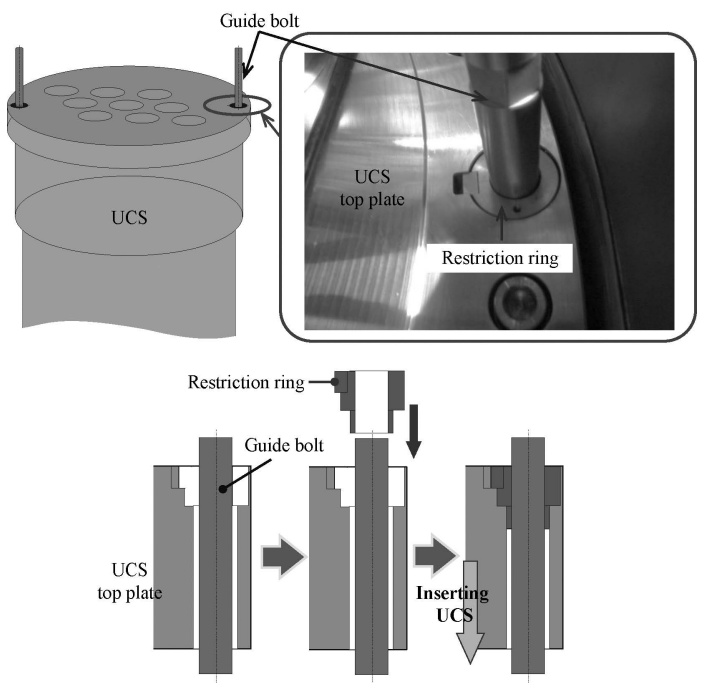

Fig. 17 Tools for UCS positioning

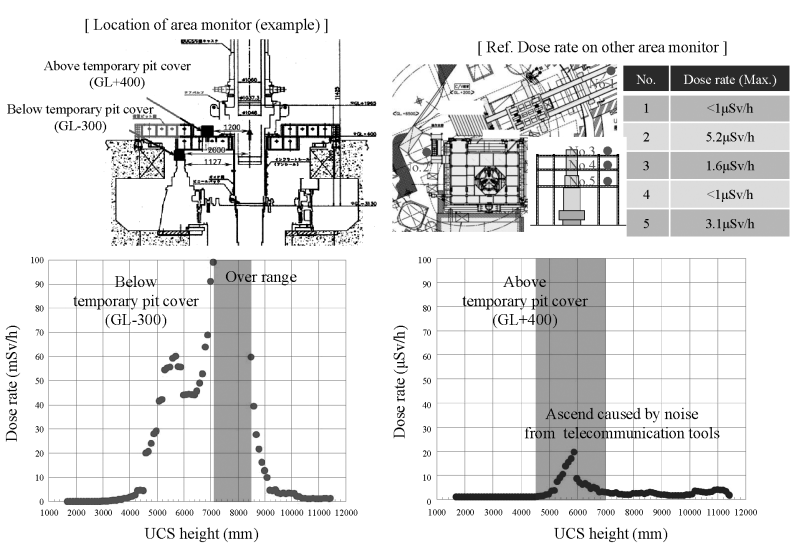

Fig. 18 Dose rate monitoring result during existing damaged UCS retrieval

キャスクに適当な遮蔽厚さを確保し，作業環境線量率を低

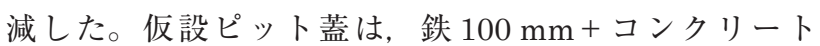
$600 \mathrm{~mm}$ 相当の遮蔽機能を有している。また，キャスク (旧UCS 用) およびドアバルブについては，原子炉容器内 の線量率測定7 に基づき評価した旧 UCS の表面線量率を 


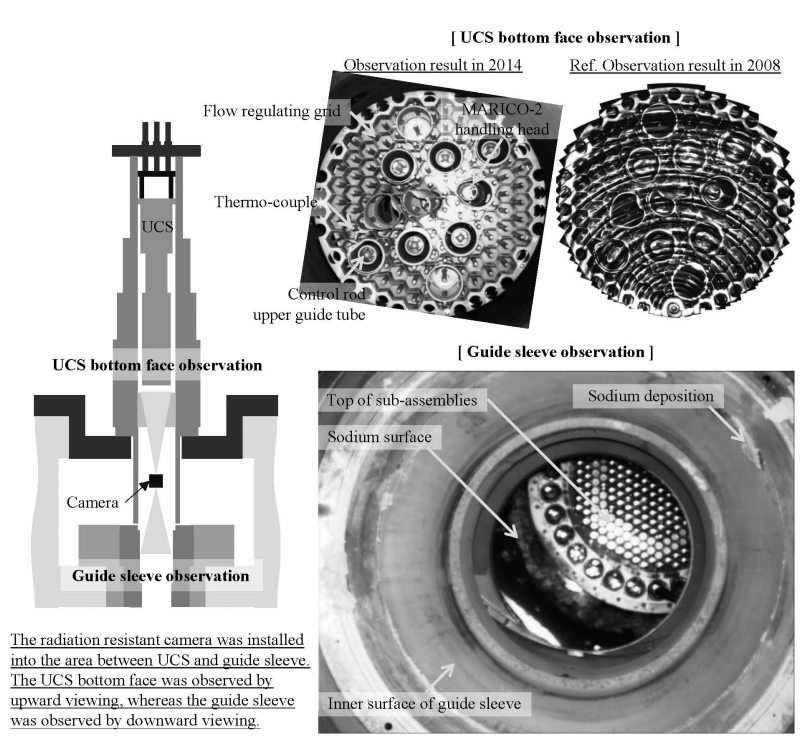

Fig. 19 Observation of bottom face of existing damaged UCS/guide sleeve

用いて，キャスク表面線量率が $1 \mathrm{mSv} / \mathrm{h}$ を十分に下回る よう遮蔽厚さ (最大： $270 \mathrm{~mm}$ 以上)を決定している。立入 を禁止した仮設ピット蓋下方のエリアにおいては，作業環 境線量率が一時的に $100 \mathrm{mSv} / \mathrm{h}$ を超過するケースが確認 されたものの，作業エリアである仮設ピット蓋上面やその 他のエリアにおける作業環境線量率は, 最大約 $5 \mu \mathrm{Sv} / \mathrm{h}$ であり，適切な遮蔽対策を講じることで被ばく低減を図る ことができた。なお，UCS 交換作業における個人最大被 ばく線量は約 $0.13 \mathrm{mSv}$, 総線量は約 1.1 人・ $\mathrm{mSv}$ であっ た。

\section{5. その他}

\section{(1) 原子炉容器内観察作業}

旧 UCS 下面および案内スリーブの観察結果を Fig. 19 に示す ${ }^{8)}$ 。当該観察作業は, 旧 UCS 引抜作業の最終段階 において，耐放射線カメラを用いて実施されたものであ り，ここでは，旧UCS下面の状況が，2008年に観察し た結果 ${ }^{9)}$ と一致し, 旧 UCS 引抜作業において, 脱落部品 が生じていないことを確認した。また，案内スリーブの観 察により，旧 UCS引抜作業において，案内スリーブに有 意な変形等はなく, 新 UCS 装荷作業への移行に問題がな いことを確認した。

\section{（２）旧 UCS 用 O リングの経年劣化調査}

旧 UCS 用 O リング（材質：エチレンプロピレンゴム $(\mathrm{EPDM}) /$ 員数 $: 2$ 本 (内側および外側 $))$ については, プ ラント状態等から, シール機能は問題ない状態であったこ とを確認しているものの，30 年以上の期間，カバーガス バウンダリとして使用した O リングを回収した稀少な機 会であることを踏まえ，外観観察，断面観察および硬度測 定による経年劣化調査を実施した。外観および断面を観察 した結果を Fig. 20 に示す。Fig. 20 に示すように, Oリ

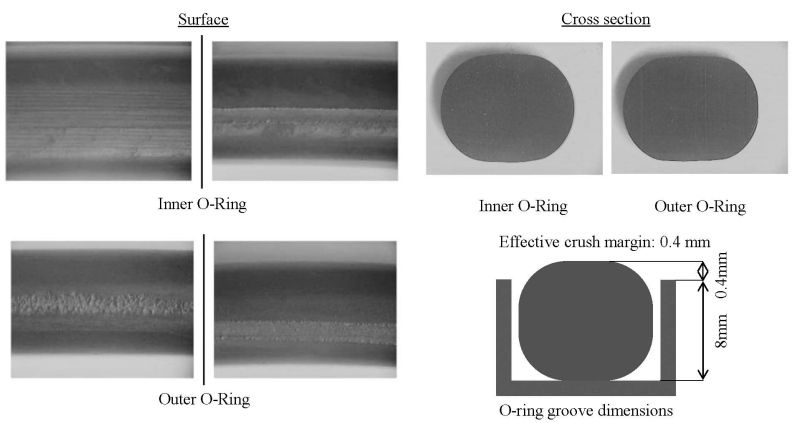

Fig. 20 Visual inspection results of the O-ring surface and cross section

ング表面にシール機能を阻害する有害な摩耗痕や圧縮痕等 がないこと，また，Ｏリングには，Ｏリング溝(幅 12 $\mathrm{mm}$ ・深さ $8 \mathrm{~mm}$ )に模した形状に圧縮影響歪が生じてい る(圧縮永久歪は一般的なシール寿命である $80 \%$ を超過) ものの, $0.4 \mathrm{~mm}$ の有効つぶし代が確保されていることが 確認できた。さらに, 硬度測定により，Oリングの硬度 はHs 81〜85 となり，使用初期 $(H s 70 \pm 5)$ と比較して大 きくなっているものの, ゴム弾性を覀失していないことが 確認されており, 経年劣化調査においても, 旧 UCS 用 $\mathrm{O}$ リングは必要なシール機能を有すると評価できた。

\section{VII. 結 論}

高放射線・高温環境の SFR における原子炬容器内補修 （観察を含む）には，軽水炉にはない技術開発が必要であ り，その技術レベルを高め, 供用期間中の保守・補修に反 映することにより SFR の信頼性の向上に寄与することが できる。SFRにおけるUCSの交換は，仏国ラプソティの 運転初期に実施された例 ${ }^{10)}$ がある程度で，世界的に稀少で ある。「常陽」では, 供用中の SFRの作業環境を考慮して 検討・開発した機材や手順を，フルモックアップ試験を経 て実機に適用し, UCS 交換作業を成功裏に終了させるこ とができた。また，フルモックアップ試験を作業トレーニ ングの場として有効に活用することで, 適切な遮蔽対策と 相まって約 4,000 人・日以上の作業員が従事した中で, 作 業員の被ばくを個人最大被ばく線量で約 $0.13 \mathrm{mSv}$, 総線 量で約 1.1 人・ $\mathrm{mSv}$ と極めて低く管理することができた。 30 年以上使用した原子炉容器内の大型構造物の交換作業 の完遂により蓄積された経験および知見は，「常陽」のみ ならずSFRにおける原子炉容器内観察・補修技術開発に 大きく資するものである。

\section{一参考文献一}

1) T. Kobayashi, "Development of inspection and repair techniques in reactor vessel of fast reactor - Endeavour to retrieve damaged components in the experimental fast reactor Joyo-,"Nihon-Genshiryoku-Gakkai Shi (J. At. 
Energy Soc. Jpn.), 54, 664-666 (2012), [in Japanese].

2) M. Takamatsu, T. Ashida, T. Kobayashi et al., "Restoration work for obstacle and upper core structure in reactor vessel of experimental fast reactor Joyo (2)," Proc. FR13, Paris, France, Mar. 4-7, 2013 (2013).

3) M. Takamatsu, T. Kobayashi, A. Nagai, Inspection and Repair Techniques in the Reactor Vessel of the Experimental Fast Reactor Joyo - Development of Repair Techniques for UCS Replacement of Joyo-, JAEA-Technology 2012-020, Japan Atomic Energy Agency (2012), [in Japanese].

4) H. Ito, M. Takamatsu, H. Kawahara et al., Inspection and Repair Techniques in the Reactor Vessel of the Experimental Fast Reactor Joyo -Development of Repair Techniques for UCS Replacement of Joyo (II) -, JAEA-Technology 2014-024, Japan Atomic Energy Agency (2014), [in Japanese].

5) H. Ushiki, E. Okuda, N. Suzuki et al., "Replacement of upper Core structure in experimental fast reactor Joyo - (2) Development of cover gas recycling system with precise pressure control一," Proc. ICAPP 2015, Nice, France, May 3-6, 2015 (2015).
6) H. Ito, N. Suzuki, T. Kobayashi et al., "Replacement of upper core structure in experimental fast reactor Joyo - (1) Existing damaged upper core structure jack-up test-," Proc. ICAPP 2015, Nice, France, May 3-6, 2015 (2015).

7) H. Ito, S. Maeda, H. Naito et al., Measurement and Analysis of In-Vessel Component Activation and Gamma Dose Rate Distribution in Joyo, JAEA-Technology 2010-049, Japan Atomic Energy Agency (2011), [in Japanese].

8) E. Okuda, J. Sasaki, N. Suzuki et al., "Replacement of upper core structure in experimental fast reactor Joyo - (3) Development of in-vessel observation techniques for UCS replacement-," Proc. ICAPP 2015, Nice, France, May 3-6, 2015 (2015).

9) M. Takamatsu, K. Imaizumi, A. Nagai et al., "Development of observation techniques in reactor vessel of experimental fast reactor Joyo," J. Power Energy Syst, 4[1], 113-125 (2010).

10) J. P. Delisle, R. Allegre, M. Besoux et al., Replacement of the Rapsodie Control Plug. Experience with an Important Operation, International Atomic Energy Agency, ISBN 920-050278-4 (1978), pp413-422, [in French]. 